\title{
Elbasani kryeqytet
}

\section{Shefqet Deliallisi}

Mundësi të humbura...

Mendimi që Elbasani të ishte kryeqyteti i Shqipërisë është i hershëm. Madje para shpalljes së shtetit të pavarur shqiptar. Në vitin 1910, në librin "Brenga e Ballkanit", Edith Durham, shkruan: "Elbasani ëndërron për një të ardhme të ndritur. Pozita e tij në qendër të vendit do të ishte ideale për kryeqytet".

\section{Mundësia e parë}

Pak ditë para Shpalljes së Pavarësisë, më 8 nëntor 1912, Ismail Qemali, në një intervistë, dhënë gazetës kryesore vjeneze, "Neue Freie Presse”, pyetjes së gazetarit se cili do të ishte kryeqyteti i Shqipërisë, do t'i përgjigjej: "Kryeqyteti i Shqipërisë mund të ishte Elbasani për shkak të pozitës së tij qendrore, por rol të madh mund të kishte edhe Vlora... Elbasani mund të ishte Uashingtoni, ndërsa Vlora, Nju-Jorku ynë”. ${ }^{1}$

Elbasani kryeqytet, ishte edhe kërkesë e Aqif Pashës, madje ai kishte marrë dhe premtimin e Ismail Qemalit. Kjo shprehej në një letër që Esat Pashë Toptani i dërgoi Aqif Pashës, më 8 shtator 1913, ku i kërkonte shkëputjen nga Qeverisja e Vlorës për t’iu bashkëngjitur qeverisë së tij. Esati i shkruan: "Ky njeri (Ismail Qemali) mundet që juve ju kabon (ju merr me të mirë) dhe ju premton se Elbasani do të bëhet kryeqytet. Vëlla, nuk e ka për hall hiç njeri qü ta caktojë tani kryeqytetin e Shqipërisë. Atë do ta caktojë Europa dhe do ta dijë vetëm princi që do të vijë këtu”.'

Përcaktimin e Elbasanit kryeqytet e përforcojnë edhe dy fakte të tjera. Një letër që Lef Nosi, nga Vlora, ministër në qeverinë e Ismail Qemalit, i dërgonte

1 Ilir Ikonomi, Pavarësia. Udhëtim i paharruar i Ismail Qemalit, UET Press, 2012, f. 96

2 A.Q.SH. Fondi Aqif Biçakçiu. Dosja 5, fletët 21/1, 21/2, 21/3. 8, shtator 1913 


\section{Sheshi para prefektures dhe bankes. Elbasan, 1940. Foto e bere nga nje ushtar italian. ((c)ADE)}

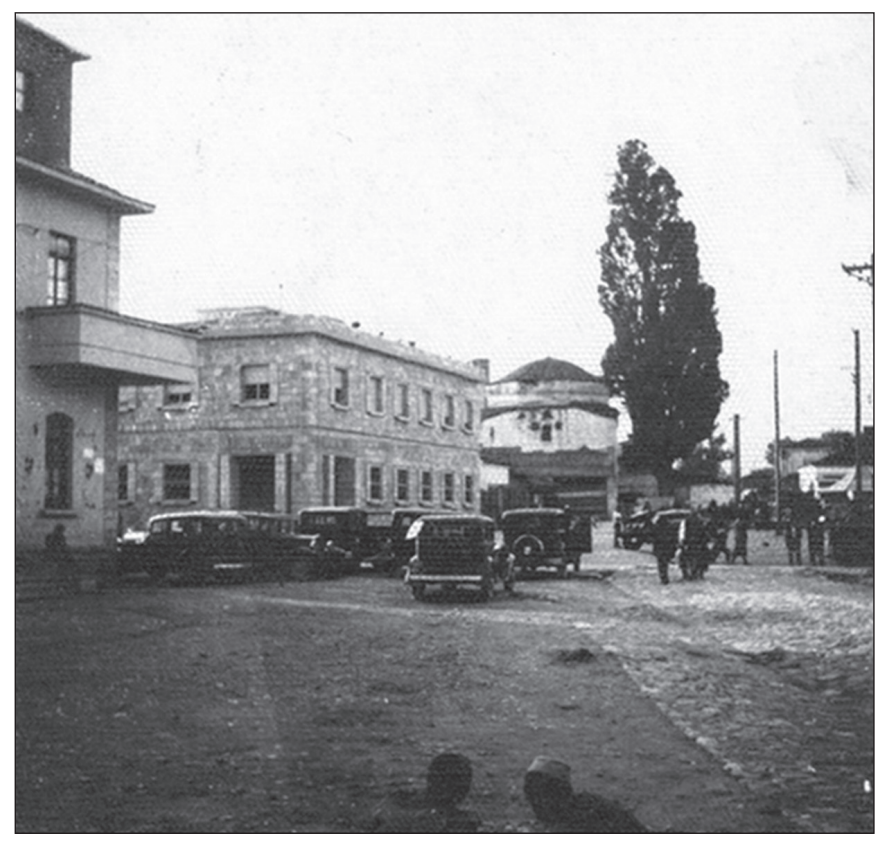

nënës së tij më 21 Shkurt 1913, ku ndër të tjera i shkruante: “E dashuna im më. ... Besoj se nuk asht për t’u vonumë ma puna, e për së shpejti do të vimë në Elbasan në Kryeqytetin e pastajshëm të Shqipniës së re..."

Po kështu, gazeta "Përlindja e Shqypnies”, organ i Qeverisë së Përkohëshme të Vlorës, në numrin e datës, 3 nëntor 1913, shkruante se Princ Vidi për kryeqytet të shtetit të ri, do të zgjidhte Elbasanin. ${ }^{3}$

Ndërkohë, Aqif Pasha, vazhdonte insistimin tek Ismail Qemali. Në letërkëmbimin e tij të mëtejshëm, më 14 nëntor 1913, i kërkonte transferimin e qeverisë nga Vlora në Elbasan dhe, Ismail Qemali i përgjigjej: "Transferimi i qendrës së Qeverisë së Përkohëshme në Elbasan është një interes kombëtar dhe në harmoni me mejtimet e mija personale, dhe do ta pranoja këtë transferim pa nguruar, por, këtë moment kur pritet të vijë mbreti, transferimi nuk është $i$ përshtatshëm se do të lindnin probleme për ardhjen e tij... ". 4

Do të ishin Fuqitë e Mëdha dhe Princ Vidi që do të përcaktonin kryeqytetin. Zgjedhja do të ishte Durrësi dhe jo Elbasani. Shkakun e kësaj përzgjedhjeje, na e jep në kujtimet e tij Charles Teleford Erikson, misionari amerikan, i cili në atë kohë ndodhej në Shqipëri: "Dikush pyet përse ishte zgjedhur ky qytet (Durrësi) prej Princit për principatën e tij? Evetmja arsye e mundshme që unë

3 Përlindja e Shipnies 20/3 nëntor 1913

4 A Q.SH, Fondi 71, Dosja 4, Dok.12031. 23 nëntor 1913 
hamendësoj është që ai të largohej papritmas në rast nevoje, dhe për këtë Durrësi ofronte përparësi të pakrahasueshme. Në rast se ai do të rrethohej, ai e dinte se nuk kishte flotë të gatshme që ta bllokonte atë nga deti..."

Kështu, Elbasani, e humbi mundësinë e parë për t’u bërë kryeqytet.

\section{Mundësia e dytë}

Vite më vonë një mundësi e dytë lindi. Në vitin 1918, u mor një nismë nga Ahmet Zogu dhe Aqif Pasha, për mbajtjen në Elbasan të një kuvendi kombëtar, si dhe u njoftuan përfaqësuesit nga trojet shqiptare për të ardhur në Elbasan. Por, kjo nismë u pengua nga austro-hungarezët. Vijmë kështu në vitin 1920, në Kongresin e Lushnjës. Dihet që organizatori kryesor i mbajtjes së Kongresit ishte Aqif Pashë Elbasani.

Me të drejtë lind pyetja: pse Kongresi nuk u mbajt në Elbasan, qytet i madh, për më tepër dhe me traditë? Vite më parë (1909), në këtë qytet ishte mbajtur me sukses Kongresi Kombëtar i Elbasanit për shkollat shqipe, në të cilin u mor dhe vendimi për hapjen e Shkollës Normale.

Pse duhej që Kongresi të mbahej në një qytezë të vogël si Lushnja?! Shkak ishin mosmarrëveshjet mes të parëve të Elbasanit, Aqif Pashës dhe Shefqet Vërlacit, të cilët ndonëse kishin lidhje të afërta familjare (ishin baxhanakë), ishin në armiqësi të ashpër mes tyre. Dihet që Vërlaci ishte më influenti në Elbasan, si dhe italofil. Gjithashtu, italianët ishin kundër mbajtjes së Kongresit, madje tentuan ta ndalonin ushtarakisht atë. Prandaj duket se Vërlaci nuk lejoi që Kongresi të mbahej në Elbasan. Ja çfarë shkruante Sejfi Vllamasi, në librin Ballafaqime politike në Shqipëri 1897-1942: "Mendimi i parë ka qenë që kongresi të bëhej në Elbasan, por mbasi bashkia e këtij qyteti ndodhej nën ndikimin e Shefqet Verlacit, nga kushtet e këtij proteksionisti të flakët, dëshira e përgjithshme për këtë vend nuk u realizua. Influenca e Verlacit në Elbasan ka qenë e madhe, sa kundërshtari i tij Aqif Pasha mori pjesë në kongres jo si delegat i Elbasanit, por si delegat i Peqinit. ${ }^{6}$ Nëse Kongresi do të ishte mbajtur në Elbasan, sigurisht që kryeqyteti i Shqipërisë do të ishte Elbasani.

Në fakt, nuk është se Kongresi i Lushnjës e zgjodhi Tiranën kryeqytet. Debati për caktimin e kryeqytetit mbeti i hapur. Pretendonin disa qytete. Elbasani ishte një prej tyre.

5 Charles Teleford Erickson, në librin "Shqiptarët - Enigma e ballkanit", pjesa e dytë, f.186

6 Sejfi VIlamasi, në librin “Ballafaqime politike në Shqipëri, 1897- 1942, f.190 


\section{Albanon}

\section{Revistë kulturore}

Ja se çfarë shkruhej në vitin 1923, në një editorial të gazetës Elbasani: “Të shofim kush nga qytetet e Shqipërisë mund t’i përmbushi konditat për kryeqytet. Korça, një nga qytetet ma të bukur të Shqipniës me kulturë, me godina të bukra e me klimë të shëndoshë, por, në një kand të Shqipniës e fare afër kufinit si të Greqisë ashtu edhe të Jugosllaviës, nuk mund të bahet kryeqytet. Gjithashtu edhe Shkodra nuk mund të bahet kryeqytet (ndonëse) sa e madhe dhe e bukur q'asht, me godina të mdha, me klimë e kulturë të shëndosh, nga shkaku se ndodhet në kandin tjetër të Shqipniës dhe afër kufinit të Jugosllavisë, veç inondasionevet (përmbytjeve) të shpeshta që ndodhin për ç'do vitë në Shkodër... Vlona e Durrsi, si qytete në buzë të detit, numërohen qytete afèr kufinit të gjithë botës e gjinden në rrezik, janë qytete të vegjël (bëhet fjalë për vitin 1923) pa godina e pa ujë e me një klimë fort të dobët e malarike. Tirana, në një vend me të vërtet të bukur, mund të zgjanohet nga të mund, por, pa ujë si për të pimë ashtu edhe për pastrim e kanalizim të tepricavet e ndytsinavet. Elbasani nga nj’anë, me gjith që sot për sot nuk ka godinat e nevojshme për t’u vendosë zyrat e duhuna (në rast nevoje, mund të plotësohen në një mot e sipër) manë tjetër përmbledhë gjith virtutat e nevojshme për një kryeqytet, nëpikpamje topografike, morale, shoqnore, politike, strategjike, gjuhsore, shëndetsore e arhitekturore. Elbasani piksëpari gjindet në kërthizët të Shqipnisë. Në kohën e okupasionit austriak ishte "trait d' union" (bashkimi) i Shqipniës së Veriut e të Jugës... Populli mbrenda në qytet asht në një shkallë kulture q’ë e meriton tjetë banorë i kryeqytetit. Popullsia e rretheve të tij asht shum e squët, e urtë, e shoqnueshme e patriotike, si me qenë banorë qyteti... Elbasani në pikpamje kulturale s'asht edhe fort larg, me krahasim të Shkodrës e të Korçës, dhe ka shpresa të mdha jo vetëm t'ja mrrië, por edhe tjja kaloj këtyneve, mbassi sot-për-sot ka 70 e sa studenta nëpër shkollat e ndryshme t’Austrisë e të Gjermanisë. ... Elbasani në pikpamje gjuhsore asht $i$ vetmi qytet, $i$ cili sikundër e lidhë politikisht Shqipniën e Veriut me atë të Jugës, ashtu edhe me gjuhë lidhë këto dy pjesë, në mënyrë që dialekti i Elbasanit, asht "trait d' union ¿" (bashkimi) i dialektevet të Gegnisë e të Toskënisë. Për këte arsye në kohën e Turqisë më 1909, Kongresi Arsimuër u mblodhë n’ Elbasan dhe vendosi hapjen e Shkollës Normale po këtu n' Elbasan, e cila prej asij kohe ishte Instituti ma $i$ nalt i Rilindjes Kombëtare. Gjithashtu po për këtë arsye, Komisioni Arsimuër në kohën e okupasionit austriak, patë pranuë dialektin e Elbasanit, si për gjuhë zyrtare të Shqipniës. Nashti së voni, edhe Ministrija e Arsimit që prej vitit 1920, po këtë dialekt ka pranuë e pëdoruë gjer më sot, si për gjuhë zyrtare të shtetit.

Në pikpamje topografike, Elbasani ka nji pozitë që të shtrihet përsipër qytetit, nëpër kodrat ose në të dy buzët e Shkuminit, që me shum arsyë të quhet kryeqytet $i$ Gegnisë dhe i Toskënisë. 
Në pikpamje shëndetsore, Elbasani asht $i$ vetmi qytet $i$ Shqipniës që meriton për kryeqytet. Ka ujë për të pimë me shumicë, i cili rrjedhe prej nji burimit të kulluëm si argjanti, e që kryen plotsisht nevojat e një kryeqyteti të banuëm prej ma se 100000 frymësh. Mjafton që ky ujë, $i$ cili buron dy orë larg qytetit, ti epet një kompanije, e cila me një sistem modern, passi t’a depozitoj, t’a sjelli në qytet me një kanal që të sigurohet mos trazimi me ujnat e shiut e tjera, dhe ashtu mund të përndahet, në ç'do shtëpië të qytetit në nji naltësië, sa t’i duhet sejcilit.

$M$ ' anë tjetër Shkumini, si një lum me ujna të shumta, e me rrymë, ka me $i$ shërbyë Elbasanit si kryeqytet, tue i dhanë ndriçimin me dritë elektrike, si dhe forcë motrike për fabrika e industrina të ndryshme. Ma në fund Shkumini po ti epet një kompanije, për t'a thelluë e për t'a përmbledhë, bahet i lundrueshëm. Kështu që Elbasani si kryeqytet mund të ketë përveç vijavet të komunikasionit toksore, por, edhe një vijë për në detë, me anën e Shkuminit.

Pra, tue u marrun parasyshë gjith këto kondita e cilsiëna që ka Elbasani, të cilat e bajnë me të vërtet të merituëshëm për kryeqytet, kujtojmë sigurisht se jo vetëm neve, por edhe përfaqsuësit e qytetevet tjera të Shqipniës, nuk kanë me ja mohuë të drejtën për me qenë kryeqytet i Shqipniës".

Kështu thuhej 106 vjet më parë në gazetën Elbasani. Artikullshkruesi anonim ndonëse pak euforik, ishte shumë vizionar dhe i ditur. Idetë që ai shpreh para 106 vjetësh, janë atraktive edhe sot, si ndërtimi i qytetit të Elbasanit në të dyja anët e Shkumbinit, apo shfrytëzimi i tij për energji elektrike, siç po tentohet sot. Megjithatë, Elbasani e humbi dhe mundësinë e dytë për kryeqytet.

\section{A ka mundësi të tretë?}

Tashmë bashkimi i Elbasanit me Tiranën nëpërmjet autostradës së re nuk është më një ëndërr. Mundësia e tretë mund të jetë Elbasani bashkëkryeqytet me Tiranën. Pse jo? Tashmë dy qytetet janë larg njëri-tjetrit vetëm 18 minuta. Endrrat jo gjithmonë mbeten ëndrra! 